\title{
Literacy media models in improving reading skill of early class students in elementary school
}

\author{
Elfia Sukma ${ }^{1}$, Ritawati Mahjuddin ${ }^{2}$, M. Habibi ${ }^{3}$ \\ ${ }^{123}$ UniversitasNegeri Padang, Padang, Indonesia
}

\section{Article Info \\ Article history: \\ Received Okt $5^{\text {th }}, 2018$ \\ Revised Okt $17^{\mathrm{h}}, 2018$ \\ Accepted Nov $3^{\text {rd }}, 2018$}

\section{Keyword:}

Literacy Media

Reading Skill

Early Class Students

\begin{abstract}
This research is based on low quality of literacy mediais used by teachers in teaching reading in the early grades in elementary school. Therefore, this study aimed to produce a valid literacy media, practical, and effective in improving reading skills of elementary school students beginning classes. The subject of research is early elementary grade students in the District of North Padang, Padang City. Literacy media is being developed is a big book, image media, and calendar stories. Development activity using 4-D model of the stages define, design, development, and disseminate. Data obtained from the results of a validation study of literacy media, observation, use of literacy media, and the learning outcomes of students' reading skills after using the media developed. The results showed that literacy mediais developed make students interested in reading and feel happy with reading material, thus helping to increase students' understanding of the content of reading.Based on these results, can conclude that the model developed literacy mediahas been a valid, practical and effective use to improve reading skills early elementary grade students.
\end{abstract}

C 2018 The Authors. Published by Redwhitepress.

This is an open access article under the CC BY-NC-SA license (https://creativecommons.org/licenses/by-nc-sa/4.0/

\section{Corresponding Author:}

\section{Elfia Sukma}

Universitas Negeri Padang, Padang, Indonesia

Email: elfiasukma105@gmail.com

\section{Introduction}

Today, the word literacy is so popular among the academic community. The low level of knowledge and understanding of information in Indonesia, often associated with low levels of community literacy. Literacy can be interpreted as an openness of insight, namely the ability of individuals in processing information and knowledge for life skills. Grabe\& Kaplan (1992) explain the narrow sense of literacy that is the ability to read and write (able to read and write). Broadly speaking, literacy is closely related to the term proficient discourse, ie the ability of the whole language includes the ability to listen, speak, read, and write, as well as the ability to think that elements in it.

Literacy is very important for elementary school students, literacy skills affect the success of learning and life. The literacy component, especially reading, is very important. Progress of the times can be followed by reading, because all the current information can be extracted and understood through reading activities. Literacy of reading will help students able to follow the rate informas. Literacy in reading makes students have a lot of knowledge, up to date with the latest information and and able to catch up. The 
existence of such an impact will make students sensitive to the situation and conditions, so as to be part of the progress of the times

Literacy of reading should be taught and cultivated since in elementary school. The reading skill acquired during reading of the beginning influences the reading skill (Zuchdi and Budiasih, 2001:57). If the foundation reading in the early class is not strong, then in the advanced reading stage students will have difficulty in having adequate reading skills. As a skill that underlies the next skill, reading the beginning really needs the teacher's attention. Therefore, the initial reading activities need service and execution maximally. Patience and thoroughness is needed in training and guiding and directing students to achieve the expected goals.

Reading the beginning is the process of learning to read for elementary school students. Students learn to acquire skills and master reading techniques and capture reading content well. Learning to read the beginning should be taught as interesting as possible, because basically reading is a tedious activity. Activity stringing word for word, sentence by sentence in finding the meaning contained in it is activity which seize attention and drain mind.

Therefore, teachers need to design learning to read well, so that students become like and used to read, so embedded in her concept that reading is a fun activity. Teachers also play a role in fostering motivation to read students. Motivation from the teacher is a source of inspiration that can foster the spirit of students in reading. Giving examples of teachers as reading ambassadors will keep students motivated to keep reading.

Learning literacy reading in the early classes also requires the right tool or media. In addition to the design of learning and teacher motivation, the use of reading media also contributes in determining the success of reading. If the learning design makes students feel happy in reading, the motivation of the teacher makes students eager to read, then the appropriate reading media will make students interested to read. That is, learning to read begins with interest, if students are interested in reading, would be easier in directing it. This is in accordance with the opinion of Yulia Anna (2011: 34) that interesting reading media, has many illustrations and color images will stimulate interest in reading children.

Characteristics of early class students who have shorter concentration ranges need support so that they are interested in what they are learning. The use of literacy mediasuch as drawings, graphs/diagrams or objects of interest can help to optimize the process of learning to read students. In addition, reading material that attracts attention will keep the child focused on the reading material. Salomon (1979) says that students will more easily understand the concept given through visual or verbal. The use of visual media will also make students better remember information than just using text media (Cowen, 1984).

This research aims to meet the needs of the above by developing a literacy media that can improve the reading skills of elementary school students early. The developed literacy mediais the big book, image media, and the alendar stories. The big book is one of the most well-used interstitals in the early classes, Curtain and Carol (2004) state that big book allows students to learn to read through how to remember and repeat the reading. As for the calendar stories, having material related to each other, enriched with images that can give space to students to explore and imagine. While the image media is a visualization media that can attract reading interest. Learning to read with the media of images makes children more motivated and interested to read and know the contents of the picture story (Wilkinson, 1984:23).

The development of the three literacy media read above, is expected to foster interest in reading elementary school students and improve their reading skills as a benchmark of reading success. In addition, the literacy media developed is expected to be used in achieving the objectives of learning in the Indonesian language contained in the curriculum with the optimum possible.

\section{Methods}

The process of developing literacy media using 4-D development model includes define, design, develop, and disseminate stages. The overall data of the research are analyzed using qualitative approach. This is in accordance with the opinion of Parkinson and Drislane (2011), that Qualitative research is using methods such as participant observation or case studies which result in a narrative, descriptive account of a setting or practice. Qualitative approach is a method of approach in the form of observation and case studies with results in the form of narrative, descriptive, and arrangement or practice. The use of qualitative research is due to the inductive nature of this study, namely the development of concepts based on data that has been obtained.

The implementation of the research is adapted to the stage of the development model used. Activities undertaken at each stage of development follow the explanation Trianto (2011a: 27) as follows. (1) The define stage defines the terms and components needed to develop the literacy medium to fit the needs of the early class students. Based on this, then at this stage conducted curriculum analysis and learning materials and student analysis. (2) Design stage, prepare literacy media developed according to the terms and components described in the previous stages. (3) Develop stage, prepared literacy media 
revised by experts, so obtained validation media validation for use. Then the media was then trialled in a limited number of schools to see its practicality and effectiveness. (4) The disseminate stage, the tested literacy media was revised again, then implemented on a wider scale. The purpose of the dissemination activity is to see the consistency of the results obtained at the development stage.

The subjects of this study were teachers and students of elementary school grade. The teacher acts as a practitioner validator, piloting literacy media, reviewing and responding to developed media. Students are involved as test subjects by acting as users and responding. The data used in the research process is primary data, because the data is obtained directly from the source. The data types used are: (1) data validation of literacy media, (2) observation data of RPP implementation, (3) teacher response result data, (4) data result of student response, and (5) reading students using literacy media.

All data used in this research is obtained by using data collecting instrument. Validity data is collected by using instrument: (1) validation instrument sheet, (2) big book validation sheet, (3) validation sheet of image media, and (4) Calendar Stories validation sheet. Data validation results are analyzed and set into the level of validity put forward Widjajanti (2008: 58) namely:

\begin{tabular}{cc}
\hline Range & Category \\
\hline $3.50-4.00$ & Very Valid \\
$3.00-3.49$ & Valid \\
$2.00-2.99$ & Less Valid \\
$1.00-1.99$ & Invalid \\
\hline
\end{tabular}

Practicality data were collected using instrument: (1) observation sheet of RPP implementation, (2) teacher reponse questionnaire, and (3) students response questionnaire. The data are analyzed in the modified practice level of Arikunto (2006: 242) as follows:

\begin{tabular}{cc}
\hline Range & Category \\
\hline $\mathbf{3 . 5 0}-\mathbf{4 . 0 0}$ & Very Practical \\
$\mathbf{3 . 0 0}-\mathbf{3 . 4 9}$ & Practical \\
$\mathbf{2 . 0 0}-\mathbf{2 . 9 9}$ & Practical Enough \\
$\mathbf{1 . 0 0}-\mathbf{1 . 9 9}$ & Less Practical \\
\hline
\end{tabular}

Effectiveness data was collected by using instrument: (1) student activity observation sheets during learning process and (2) reading result score sheet. The score of learning achievement of reading skill was analyzed and converted into the learning result pursuant pursued by Purwanto (2006: 102), with the threshold limit is 76 (good).

\begin{tabular}{cc}
\hline Value & Assessment Criteria \\
\hline $\mathbf{8 6 - 1 0 0}$ & Very Good \\
$\mathbf{7 6}-\mathbf{8 5}$ & Good \\
$\mathbf{6 0 - 7 5}$ & Enough \\
$<59$ & Less \\
\hline
\end{tabular}

\section{Research Result and Discussion}

The result of this research is literacy media (big book, image media, and calendar stories) for a valid, practical, and effective first-grade reading in elementary school class.

\section{Validityof Literacy Media}

Literacy media validation is performed by experts and practitioners by scoring on each assessment indicator.Indicators of assessment on big bookmedia, image media, and calendar stories are divided into several aspects, namely: (1) content feasibility aspects , (2) aspects of language usage , (3) aspect of presentation pattern, and (4) aspects of graffiti.Assessment indicators on each aspect vary, depending on the type of literacy media.Assessment is carried out by giving a score of 1 - 4 on each assessment indicator, with criteria: (1) unsuitable, (2) less appropriate, (3) appropriate, (4) very appropriate. The results of literacy media validation by experts and practitioners can be seen in the following table. 
Table 1. Validation Result of Big Book,Image Media, danCalendar Stories

\begin{tabular}{llcccccc}
\hline No & \multicolumn{1}{c}{ Aspect of } & \multicolumn{2}{c}{ Big Book } & \multicolumn{2}{c}{ Image Media } & \multicolumn{2}{c}{ Calendar Stories } \\
\cline { 2 - 7 } & \multicolumn{1}{c}{ Assessment } & Average & Categori & Average & Categori & Average & Categori \\
1. & $\begin{array}{l}\text { Feasiblity } \\
\text { Content }\end{array}$ & 3.63 & Very Valid & 3.50 & Very Valid & 3.67 & Very Valid \\
& & & & & & & \\
2. & Language Usage & 3.60 & Very Valid & 3.38 & Valid & 3.50 & Very Valid \\
3. & $\begin{array}{l}\text { Presentation } \\
\text { Patterns }\end{array}$ & 3.48 & Valid & 3.52 & Very Valid & 3.42 & Valid \\
4. & Graffiti & & & & & & \\
& $\quad$ Average & 3.76 & Very Valid & 3.60 & Very Valid & 3.63 & Very Valid \\
& & 3.62 & Very Valid & 3.50 & Very Valid & 3.56 & Very Valid \\
\hline
\end{tabular}

Based on table 1 above, it is concluded that every aspect of big book literacy media, image media, and calendar stories meets the criteria of validity. The results of the validator assessment of the big book, indicating that the content feasibility aspects, the use of language, and graffiti have criteria "very valid", while the aspect of the presentation pattern has "valid" criteria. The overall big book validity level is 3.62 "very valid" criteria.

Assessment of the image media shows that the content feasibility aspect, presentation pattern, and grafffti have "very valid" criteria, while the language usage aspect has "valid" criteria. The overall validity level of the image media is 3.50 with the criterion "very valid". Assessment of the calendar stories shows that the content feasibility aspect, the use of language and the presentation pattern have the category "very valid", while the aspect of the presentation pattern has "valid" criteria. The overall calendar stories validity level is 3.56 "very valid" criteria.

Based on these results, it was concluded that the big book, image media, and calendar storiesdeveloped were declared valid and suitable to be used in improving the reading skill of elementary school students.

\section{Practicality of Literacy Media}

Practical or practical, meaning easy to implement, easy to check, and equipped with clear instructions, making it easier for teachers and students in the use of learning tools (Arikunto, 2010: 62). The level practicality of literacy media developed is seen from 3 aspects, namely: (1) The implementation of learning using literacy media. (2) teacher's response to literacy media, and (3) student's response to literacy media. Here are described the results of these three aspects.

\section{Learning Implementation}

Observation of instructional learning is intended to see whether the learning activities using the developed literacy mediaimplemented well according to the designed RPP. Observations were conducted by 2 observers in 3 lessons using the observation indicator that has been prepared. The first lesson uses the big book, the second lesson uses the image media, and learning when using calendar stories media. All observation indicators are grouped into three activities, namely (1) initial activities, (2) core activities, and (3) final activities. The following presented the results of the implementation of learning using the media developed.

Table 2. Level of Learning Implementation Using Literacy Media

\begin{tabular}{|c|c|c|c|c|c|c|c|}
\hline \multirow[t]{2}{*}{ No } & \multirow{2}{*}{$\begin{array}{c}\text { LerningAcitv } \\
\text { ities }\end{array}$} & \multicolumn{2}{|c|}{ Big Book } & \multicolumn{2}{|c|}{ Image Media } & \multicolumn{2}{|c|}{ Calendar Stories } \\
\hline & & Average & Category & Average & Kategori & Average & Kategori \\
\hline 1 & $\begin{array}{l}\text { Initial } \\
\text { Activity }\end{array}$ & 3.72 & Very Practical & 3.43 & Practical & 3.67 & Very Practical \\
\hline 2 & $\begin{array}{l}\text { Core } \\
\text { Activities }\end{array}$ & 3.63 & Very Practical & 3.54 & Very Practical & 3.63 & Very Practical \\
\hline 3 & $\begin{array}{l}\text { End } \\
\text { Activities }\end{array}$ & 3.60 & Very Practical & 3.40 & Practical & 3.47 & Practical \\
\hline
\end{tabular}




\begin{tabular}{|c|c|c|c|c|c|c|}
\hline Average & 3.65 & Very Practical & 3.46 & Practical & 3.59 & Very Practical \\
\hline
\end{tabular}

Based on these results, it can be concluded that the learning activities using literacy mediadeveloped well done and can help students in reading learning in the early class. Overall, the learning of reading in the early classes using the big book media earned an average of 3.65 categories of very practical value. Overall learning activities using big book media, both initial activities, core activities, and end activities also earn very practical categories. Then, the reading learning in the early class using the image media obtained an average grade of 3.46 practical categories. The core activities in this learning acquire a very practical category. While the initial activities and activities finally obtained the practical category. Next, reading learning in the early grades using calendar stories media earns an average 3.59 very practical category score. The initial activities and core activities in this learning obtained a very practical category, while for the event finally obtained the practical category.

Overall, the reading learning activities contained in the designed draft can be effectively implemented thanks to the use of developed literacy media. In the initial activities, students are able to express their opinions related to the contents of the picture. In the core activities, students are excited to read stories that contain literacy mediawith a loud voice. In addition, students also find no difficulty in answering the questions given. In the final activity, students look cheerful in telling the contents of the text that is read.

\section{Analysis of the Teacher's Response}

As an educational practitioner, teachers need to respond to the quality of literacy mediadeveloped. The goal is to see if the literacy mediadeveloped is suitable and easy to use by teachers in teaching reading learning in elementary school. The practicality of literacy media use can be seen from the scores given to the following aspects: (1) practicality of use, (2) material conformity to time, (3) use of pictures and illustrations, (4) use of language and sentences, (5) impact on learning. The teacher responses are presented below.

Table 3.Teacher'a Responses to Literacy Media

\begin{tabular}{clcccccc}
\hline No & \multicolumn{1}{c}{$\begin{array}{c}\text { Aspect of } \\
\text { Assessment }\end{array}$} & \multicolumn{2}{c}{ Big Book } & \multicolumn{2}{c}{ Image Media } & \multicolumn{2}{c}{ Calendar Stories } \\
\cline { 2 - 8 } $\mathbf{1}$ & $\begin{array}{l}\text { Pverage } \\
\text { Practicality of use }\end{array}$ & 3.67 & Category & Average & Category & Average & Category \\
$\mathbf{2}$ & $\begin{array}{l}\text { Material Suitability } \\
\text { of Time }\end{array}$ & 3.75 & Very Practical & 3.33 & Practical & 3.42 & Practical \\
$\mathbf{3}$ & $\begin{array}{l}\text { Use of images and } \\
\text { Illustrations }\end{array}$ & 3.75 & Very Practical & 3.33 & Practical & 3.46 & Practical \\
$\mathbf{4}$ & $\begin{array}{l}\text { Use of language and } \\
\text { sentences }\end{array}$ & 3.67 & Very Practical & 3.63 & Very Practical & 3.67 & Very Practical \\
$\mathbf{5}$ & $\begin{array}{l}\text { Impact on learning } \\
\text { Average }\end{array}$ & 3.83 & Very Practical & 3.67 & Very Practical & 3.67 & Very Practical \\
& 3.73 & Very Practical & 3.49 & Practical & 3.57 & Very Practical \\
\hline
\end{tabular}

Overall, the teacher's response to big book media is 3.73 with very practical category, 3.49 to image media with practical category, and 3.57to calendar stories with very practical category. The result of the teacher's response, indicating that the teacher assessed the literacy media developed is practical and easy to use in teaching reading in low class. Teachers also argue that the literacy media developed has a positive impact on learning. The use of animated images in the media, makes students enthusiastic in following learning reading. Students look eager to read the sentence contained in the next picture.

The use of language in literacy media also in accordance with the level of language development of low-grade students.Presentation of stories through short sentences, making students quickly understand every story line contained in literacy media. So that students can easily understand the story as a whole. Literacy mediadeveloped also helps teachers in the learning process. The existence of media usage guidelines, make teachers know how best to convey the story contained in the literacy media

\section{Analysis of Student's Responses}

The development of this literacy media is intended for elementary school students, hoping to increase reading interest and their reading skill. Therefore, to see the level of practicality of literacy media developed, also required a student response that notabennya is the subject of research. The purpose of this analysis is to know the real condition of literacy media when used by students. Through this analysis, it will be seen whether students love the literacy media or not. Analysis of student responses carried out by giving a questionnaire containing statements related literacy media developed. Students are required to 
rate each statement according to the conditions they feel during or after using the developed literacy media. Here are presented the results of student responses more.

Tabel 4.Student's Response to Literacy Media

\begin{tabular}{|c|c|c|c|c|c|c|c|}
\hline \multirow[t]{2}{*}{ No } & \multirow[t]{2}{*}{ Statement } & \multicolumn{2}{|c|}{ Big Book } & \multicolumn{2}{|c|}{ Image media } & \multicolumn{2}{|c|}{ Calendar stories } \\
\hline & & Average & Category & Average & Category & Average & Category \\
\hline 1 & Displaybig book/ image media & 3.78 & Very & 3.68 & Very & 3.72 & Very \\
\hline 2 & $\begin{array}{l}\text { Big book/image media/calendar } \\
\text { storieshave aclear and } \\
\text { interestingimageto look at. }\end{array}$ & 3.66 & $\begin{array}{c}\text { Very } \\
\text { Practical }\end{array}$ & 3.42 & Practical & 3.48 & Practical \\
\hline 3 & $\begin{array}{l}\text { Picturesofbig book/image } \\
\text { media/calendar stories inaccordance } \\
\text { with the contents of the story. }\end{array}$ & 3.88 & $\begin{array}{c}\text { Very } \\
\text { Practical }\end{array}$ & 3.78 & $\begin{array}{c}\text { Very } \\
\text { Practical }\end{array}$ & 3.83 & $\begin{array}{c}\text { Very } \\
\text { Practical }\end{array}$ \\
\hline 4 & $\begin{array}{l}\text { Bigbook/image media/calendar } \\
\text { storieshas an interesting and varied } \\
\text { color. }\end{array}$ & 3.82 & $\begin{array}{c}\text { Very } \\
\text { Practical }\end{array}$ & 3.58 & $\begin{array}{c}\text { Very } \\
\text { Practical }\end{array}$ & 3.67 & $\begin{array}{c}\text { Very } \\
\text { Practical }\end{array}$ \\
\hline 5 & $\begin{array}{l}\text { Postsbig book/image media /calendar } \\
\text { storiesclear and easy to read. }\end{array}$ & 3.78 & $\begin{array}{c}\text { Very } \\
\text { Practical }\end{array}$ & 3.63 & $\begin{array}{c}\text { Very } \\
\text { Practical }\end{array}$ & 3.67 & $\begin{array}{c}\text { Very } \\
\text { Practical }\end{array}$ \\
\hline 6 & $\begin{array}{l}\text { Sentences big book/image media } \\
\text { /calendar stories are short and easy to } \\
\text { understand. }\end{array}$ & 3.68 & $\begin{array}{c}\text { Very } \\
\text { Practical }\end{array}$ & 3.68 & $\begin{array}{c}\text { Very } \\
\text { Practical }\end{array}$ & 3.75 & $\begin{array}{c}\text { Very } \\
\text { Practical }\end{array}$ \\
\hline 7 & $\begin{array}{l}\text { Story bigbook/image media/calendar } \\
\text { stories interesting and not boring. }\end{array}$ & 3.75 & $\begin{array}{c}\text { Very } \\
\text { Practical }\end{array}$ & 3.46 & Practical & 3.48 & Practical \\
\hline 8 & $\begin{array}{l}\text { Storybig book/image media/calendar } \\
\text { stories iseasy to understand and the } \\
\text { content corresponds to the picture. }\end{array}$ & 3.85 & $\begin{array}{c}\text { Very } \\
\text { Practical }\end{array}$ & 3.76 & $\begin{array}{c}\text { Very } \\
\text { Practical }\end{array}$ & 3.76 & $\begin{array}{c}\text { Very } \\
\text { Practical }\end{array}$ \\
\hline 9 & $\begin{array}{l}\text { Story big book/image media/calendar } \\
\text { storiesprovide valuable lessons. }\end{array}$ & 3.92 & $\begin{array}{c}\text { Very } \\
\text { Practical }\end{array}$ & 3.72 & $\begin{array}{c}\text { Very } \\
\text { Practical }\end{array}$ & 3.83 & $\begin{array}{c}\text { Very } \\
\text { Practical }\end{array}$ \\
\hline 10 & $\begin{array}{l}\text { Big book/image } \\
\text { media/calendarhelped me inreading } \\
\text { thestory. }\end{array}$ & 3.72 & $\begin{array}{c}\text { Very } \\
\text { Practical }\end{array}$ & 3.70 & $\begin{array}{c}\text { Very } \\
\text { Practical }\end{array}$ & 3.75 & $\begin{array}{c}\text { Very } \\
\text { Practical }\end{array}$ \\
\hline 11 & $\begin{array}{l}\text { Big book/image media/calendar } \\
\text { storiesmake me interested and active } \\
\text { in learning.. }\end{array}$ & 3.82 & $\begin{array}{c}\text { Very } \\
\text { Practical }\end{array}$ & 3.52 & $\begin{array}{c}\text { Very } \\
\text { Practical }\end{array}$ & 3.68 & $\begin{array}{c}\text { Very } \\
\text { Practical }\end{array}$ \\
\hline 12 & $\begin{array}{l}\text { Big book/ image media/calendar } \\
\text { stories } \\
\text { makes it easy for me to answer } \\
\text { questions. }\end{array}$ & 3.72 & $\begin{array}{c}\text { Very } \\
\text { Practical }\end{array}$ & 3.52 & $\begin{array}{c}\text { Very } \\
\text { Practical }\end{array}$ & 3.72 & $\begin{array}{c}\text { Very } \\
\text { Practical }\end{array}$ \\
\hline 13 & $\begin{array}{l}\text { Big book/image media/calendar } \\
\text { make it easy for me to tell. }\end{array}$ & 3.63 & $\begin{array}{c}\text { Very } \\
\text { Practical }\end{array}$ & 3.42 & Practical & 3.50 & $\begin{array}{c}\text { Very } \\
\text { Practical }\end{array}$ \\
\hline & Rata-rata & 3.77 & $\begin{array}{c}\text { Very } \\
\text { Practical }\end{array}$ & 3.60 & $\begin{array}{c}\text { Very } \\
\text { Practical }\end{array}$ & 3.67 & $\begin{array}{c}\text { Very } \\
\text { Practical }\end{array}$ \\
\hline
\end{tabular}

Based on the results of the table above, the overall response rate of students to the big book media is 3.77 with a very practical category. Then the level of student response to the media picture story is 3.60 with the category very practical. The level of student response to the calendar stories media is 3.68 with very practical category.

These results indicate that students respond positively to the developed literacy media. Overall, students judge that literacy mediahas an interesting look to read and learn. The use of images that are clear, interesting, and in accordance with the contents of the story, it helps students in mamahami each storyline well. The story presented also matches the characteristics of the early elementary school students and contains valuable lessons that students can apply in everyday life. In general, students feel that the use of literacy media is helpful to them in reading. The presentation of stories through short sentences and language that is easy to understand, making students able to retell the story contained in literacy media.

Based on the result of the data of practicability which has been described, it can be concluded that the developed literacy media is stated practically. This can be seen from: (1) the implementation of 
learning to read in the early class well, (2) the convenience felt by the teacher in teaching reading learning, (3) positive response of students showing that literacy media very interesting for them.

\section{Efektivitas Literacy media}

Effectiveness comes from the effective word of compatibility and conformity. Media effectiveness means the extent to which the media usage developed can meet the expected results. The effectiveness of the learning program seen from the success of the program leads the students to achieve the established instructional objectives and provide an active and attractive learning experience (Dirman, 2014: 56). The effectiveness of literacy media is seen from the learning achievement of students' reading skill in every indicator of determined learning success. These indicators are: (1) the ability to read aloud text, (2) the ability to answer questions, and (3) the ability to retell the contents of the text. Literacy media is said to be effective, if student learning outcomes are classical beyond the minimum KriteriaKetuntasan Minimal $(\mathrm{KKM})$ defined is 76 . Here are presented the results of learning skills of reading students using literacy media developed.

Table 5. Learning Outcomes of Student Reading Skills

\begin{tabular}{|c|c|c|c|c|c|c|c|}
\hline $\mathbf{N}$ & Success & \multicolumn{2}{|c|}{ Big Book } & \multicolumn{2}{|c|}{ Image media } & \multicolumn{2}{|c|}{ Calendar Stories } \\
\hline $\mathbf{o}$ & Indicators & Average & Category & Average & Category & Average & Category \\
\hline 1 & $\begin{array}{l}\text { Abilitystudents to } \\
\text { reading aloud text. }\end{array}$ & 85.67 & Good & 84.83 & Good & 84.83 & Good \\
\hline 2 & Abilitystudents to & 91.67 & Very Good & 88.50 & Very & 89.33 & Very \\
\hline & answer questions. & & & & Good & & Good \\
\hline 3 & $\begin{array}{l}\text { Ability students } \\
\text { to retell the } \\
\text { contents of the } \\
\text { text. }\end{array}$ & 82.17 & Good & 81.33 & Good & 83.17 & Good \\
\hline & Average & 86.50 & Very Good & 84.88 & Good & 85.77 & Good \\
\hline
\end{tabular}

The table above shows that the average score of reading skill of students using big book media is 86.50 with very good category. The average score of students' reading skills using the image media is 84.88 with good category. While the average score of reading skill of students using big book media is 86.50 with very good category.

Based on the table, it is concluded that the reading learning in the early classroom using the developed literacy media has reached the minimum criterion specified minimum. Literacy media developed effectively used in improving learning process and learning outcomes of reading elementary school students. Results indicator ability to read aloud texts, indicating that students have been able to read aloud by referring to the criteria set. Students are able to read the text with a loud voice and proper pronunciation. Students also point to every sentence of text that is read using their index finger. In addition, students are seen moving their heads along the lines of text that is being read. All three of the above is a characteristic of loud reading activity.

The indicator results answered the question, indicating that the student is able to answer each question very well. Student enthusiasm in reading aloud texts, making them understand the content of the text as a whole, so as to answer each question correctly. The result indicator tells the contents of the text, indicating that the student is able to tell the contents of the text that is read with his own sentence. In the case of storytelling, students seem confident enough to tell briefly the contents of the text that he read. Although still looks shy, but overall the story presented by students quite in accordance with the text content. The main thing in this activity is the students are able to tell by using their own language which sometimes mixed with the local language of each.

\section{Conclusions and Suggestions}


Based on the result of the research and discussion above, the following conclusions are obtained: (1) A valid, practical and effective literacy media has been used in the learning process of reading in elementary school. (2) Literacy media developed include big book, image medias, and calendar stories. (3) The validity of the literacy media is derived from the results of expert judgment in terms of content feasibility, language usage, presentation patterns, and graffiti. The results of the assessment indicate that the literacy media developed is suitable for reading learning in the early grades. (4) Practicalityliteracy media obtained from the observation of learning using media developed, teacher response, and student responses. The results of observation indicate that literacy media make learning process of reading more effective and meaningful. Literacy media also makes students interested and active in reading learning. (5) The effectiveness of literacy media is obtained from the learning result of students' reading skill after using the developed media. The results of the assessment indicate that the value obtained by students in classical exceeds the minimum criterion of defined minimum criteria.

Based on the conclusions obtained, it is recommended that elementary school teachers and education practitioners can use the literacy media developed in achieving the objectives of Indonesian language learning contained in the curriculum optimally.

\section{Reference}

Arikunto, Suharsimi. 2006. ProsedurPenelitian: SuatuPendekatanPraktik. Jakarta: RinekaCipta.

Arikunto, Suharsimi. (2010). Dasar-DasarEvaluasiPendidikan.BumiAksara : Jakarta.

Curtain, Helena Anderson \& Carol Ann. 2004. Language And Children : Making The Match. Boston, USA: Pearson.

Dirman, J. C. 2014. PengembanganKurikulumDalamRangkaImplementasiStandar Proses PendidikanSiswa.Jakarta: AsdiMahasatya.

G. Parkinson, R. Drislane. 2011, Qualitative Research. In Online Dictionary Of The Social Sciences. Http:// Bitbucket.Icaap.Org/Dict.P1.

Purwanto, Ngalim. 2006. Administrasi Dan SupervisiPendidikan. Bandung: RemajaRosdakarya.

Purwanto, Ngalim. 2010. Dasar-DasarEvaluasiPendidikan. BumiAksara : Jakarta.

Salomon, Gavriel. 1979. Interaction Of Media, Cogni -tion, Dan Learning. San Francisco, CA: Jossey Bass.

Tompkins, Gaile E. 1994. TechingWriting:Balancing Process and Product. New York:Macmilan College Publishing Company.

Trianto. 2011a. Mendesain Model PembelajaranInovatif-Progresif.Jakarta: KencanaPrenada Media Group.

Walkinson, Gene. 1984. Media DalamPembelajaranPenelitianSelama 60 Tahun. Jakarta: Rajawali.

Widjajanti, Endang. 2008. KualitasLembarKerjaSiswa(Online), (Staff.Uny.Ac.Id/System/Files/acara Pengabdian/Endang/Kualitas-Lks.Pdf, Diaksespadatanggal14Juli 2018.

Yulia, Anna. 2005. Cara MenumbuhkanMinat Baca Anak. Jakarta: Elex Media Komputindo.

Zuchdi, Darmiyati\&Budiasih. 1996. PendidikanBahasa Dan Sastra Indonesia Di KelasRendah. Jakarta: Depdikbud. 